\title{
Virtual tour as an effective method for promotion of enterprise
}

\author{
Potapiuk L. ${ }^{*}$, Masovets 0. \\ Lutsk national technical university, Lutsk, Ukraine
}

Received: $24.12 .2018 \quad$ Accepted: 15.01 .2019

\begin{abstract}
The article investigates virtual reality as the most effective way of presenting information in our time and an effective way to promote the enterprise. The history of creating virtual tours is analyzed. It was noted that the first virtual tour was designed by engineer Colin Johnson (1994, Great Britain). His innovative presentation consisted of a management system (on a computer) and panoramas (on a disk). Especially for this innovative presentation, a unique navigation program was developed. The history of virtual tours began precisely with museums that continued this tradition. Most virtual tours are created using GoogleArtProject. It was emphasized that during the rapid development of information technology, 3D tours became popular in various fields of human activity: from services to research. Modern man works more often, carries out business operations, studies, travels, communicates, leisure and even rest in a virtual format. The main advantages of spherical panoramas and 3D tours for both buyers and sellers are highlighted. It is revealed that virtual panoramas contribute to the image of the company, its high-tech, innovation-investment attractiveness. Determined the role of Google in creating Google Maps and GoogleBusinessView. For buyers, the advantage of spherical panoramas and 3D tours is a significant saving of time (you can familiarize yourself with the object at any convenient time); possibility of preliminary, detailed review of all available from the seller of potentially interesting objects. For sellers, the main benefits of spherical panoramas and $3 \mathrm{D}$ tours are increasing interest in the company, and thus attracting new customers (virtual tours make considerable interest to most visitors, increase the number of potential customers and increase company revenue); originality and attractiveness (presentation and advertising is different from most competitors in a way of more interest than ordinary photos or text); reducing the time between creating a virtual tour and familiarizing him with the buyer. The importance of the Google team for the introduction of virtual tours to expand the modern business is underlined. It is proved that virtual tours at the enterprises become an effective marketing tool that will enable to increase the number of potential and real customers and to establish cooperation with investors and partners. And so, today we have every opportunity to modernize the existing technological environment through the creation of virtual tours in the enterprises.
\end{abstract}

Key words: information technologies, virtual reality, 3D tours, enterprises, company image.

\section{Віртуальний тур як ефективний спосіб просування підприємства}

\author{
Потапюк Л. М., Масовець О. А. \\ Луцький національний технічний університет, Луцьк, Україна
}

\begin{abstract}
Анотація. У статті досліджується віртуальна реальність як найефективніший шлях подачі інформації в наш час і ефрективний спосіб просування підприємства. Проаналізовано історію створення віртуальних турів. Зазначено, що перший віртуальний тур розробив інженер Колін Джонсон (1994р., Великобританія). Иого новаторська презентація складалася із системи управління (на комп'ютері) і панорам (на диску). Спеціально для цієї новаторської презентації була розроблена унікальна програма навігації. Історія віртуальних турів почалася саме з музеїв, які продовжили цю традицію. Більшість віртуальних турів створені за допомогою GoogleArtProject. Підкреслено, що у час бурхливого розвитку інсормаційних технологій саме 3D-тури стали популярними в різних галузях людської діяльності: від сфери послуг до наукових досліджень. Сучасна людина частіше працює, здійснює бізнес-операції, навчається, подорожує, спілкується, проводить дозвілля і навіть відпочиває у віртуальному форматі. Виділені основні переваги сфреричних панорам і 3D-турів як для покупців, так і для продавців. Для покупців перевагою сфреричних панорам і 3D-турів $\epsilon$ значна економія часу (ознайомитися з об'єктом можна в будь-який зручний для них момент); можливість попереднього, детального огляду всіх наявних у продавця потенційно цікавих об'єктів. Для продавців основними перевагами ссферичних
\end{abstract}

Corresponding Author: PotapiukLiliiaMykolaivna. Tel. +38(050) 17-27-719. E-mail: potapiuk_@bbigmir.net Lutsk National Technical University,75, Lvivska str., Lutsk, Volyn Region, Ukraine, 43018.

Вiдnовідальний автор: Потапюк Лілія Миколаївна. Тел. +38(050) 17-27-719. E-mail: potapiuk_@@bigmir.net Луцький національний технічний університет, вул. Львівська, 75, м. Луцьк, Волинської обл., Україна, 43018. 
панорам і 3D-турів є підвищення інтересу до компанії, а отже, залучення нових клієнтів (віртуальні тури викликають значний інтерес у більшості відвідувачів, збільшують число можливих клієнтів та підвищують доходи компанії); оригінальність і привабливість (презентація і реклама відмінним від більшості конкурентів способом, що викликає більший інтерес, ніж звичайні фотографії або текст); скорочення часу між створенням віртуального туру і знайомством з ним покупцем. Виявлено, що віртуальні панорами сприяють підвищенню іміджу компанії, її високотехнологічній, інноваційно-інвестиційній привабливості. Визначено роль компанії Google у створенні Google Maps i GoogleBusinessView. Підкреслено значення команди Google із впровадження віртуальних турів щодо розширення сучасного бізнесу. Доведено, що віртуальні тури на підприємствах стають ефективним маркетинговим інструментом, який дасть можливість збільшити кількість потенційних і реальних замовників та налагодити співпрацю з інвесторами й партнерами. А отже, на сьогодні маємо всі можливості модернізувати наявне технологічне середовище через створення на підприємствах віртуальних турів.

Ключові слова:інформаційні технології, віртуальна реальність, 3D-тури, підприємства, імідж компанії.

\title{
Виртуальный тур как эффрективный способ продвижения предприятия
}

\author{
Потапюк Л. Н., Масовец Е. А.
}

Луцкий национальный технический университет, Луцк, Украина

\begin{abstract}
Аннотация. В статье исследуется виртуальная реальность как эффективный путь подачи информации в наше время и эффективный способ продвижения предприятия. Проанализирована история создания виртуальных туров. Отмечено, что первый виртуальный тур разработал инженер Коленей Джонсон (в 1994 г., Великобритания). Его новаторская презентация состояла из системы управления (на компьютере) и панорам (на диске). Специально для этой новаторской презентации была разработана уникальная программа навигации. История виртуальных туров началась именно с музеев, которые продолжили эту традицию. Большинство виртуальных туров создано с помощью GoogleArtProject. Подчёркнуто, что в период бурного развития инфрормационных технологий именно 3D-туры стали популярными в различных областях человеческой деятельности: от сферы услуг к научным исследованиям. Современный человек чаще работает, осуществляет бизнес-операции, учится, путешествует, общается, проводит досуг и даже отдыхает в виртуальном формате. Выделены основные преимущества сфрерических панорам и 3D-туров как для покупателей, так и для продавцов. Для покупателей преимуществом сферических панорам 3d-туров является значительная экономия времени (ознакомиться с объектом можно в любой удобный для них момент); возможность предыдущего, подробного осмотра всех имеющихся у продавца потенциально интересных объектов. Для продавцов основными преимуществами сферических панорам и 3d-туров является повышение интереса к компании, а следовательно, привлечение новых клиентов (виртуальные туры вызывают значительный интерес у большинства посетителей, увеличивают число возможных клиентов и повышают доходы компании); оригинальность и привлекательность (презентация и реклама отличающимся от большинства конкурентов способом, который вызывает больше интереса, чем обычные фотографии или текст); сокращение времени между созданием виртуального тура и знакомством покупателя с ним. Выявлено, что виртуальные панорамы способствуют повышению имиджа компании, её высокотехнологичной, инновационно-инвестиционной привлекательности. Определена роль компании Google в создании GoogleMaps и GoogleBusinessView. Подчеркнуто значение команды Google по внедрению виртуальных туров в расширении современного бизнеса. Доказано, что виртуальные туры на предприятиях становятся эффективным маркетинговым инструментом, который позволит увеличить количество потенциальных и реальных заказчиков и наладить сотрудничество с инвесторами и партнерами. А следовательно, на сегодня имеем все возможности модернизировать имеющуюся технологическую среду через создание на предприятиях виртуальных туров.
\end{abstract}

Ключевые слова: информационные технологии, виртуальная реальность, 3D-туры, предприятия, имидж компании.

\section{Bcmyn}

Успішне функціонування підприємств в Україні характеризується інтенсивним розвитком інноваційних процесів. Істотною особливістю цієї тенденції $€$ необхідність пошуку нових технологій рекламування своєї компанії. Широкомасштабне застосування сучасних інформаційних технологій останнім часом змушує розробляти нові способи презентації інформації. Тому у час бурхливого розвитку цих технологій сааме 3D-тури стали популярними в різних галузях людської діяльності: від сфери послуг до наукових досліджень. Віртуальні тури дозволяють бачити і переглядати навколишнє середовище не подорожуючи безпосередньо до місця знаходження. Через 3D-тури люди отримують інформацію та досвід, які в інший спосіб не можуть бути доступними, попередньо переглянути місцезнаходження до фактичного відвідування і зробити більш обірунтовані висновки та вибір. 
А отже, віртуальна реальність $€$ тією потужною та переконливою технологією, яка націлена імітувати реальний світ за допомогою комп'ютерних технологій, посилити емоційний та естетичний вплив на людей. Це робить віртуальні тури одним із найефективніших шляхів подачі інформації у наш час.

Meта роботи: Аналіз ефективності впровадження віртуальних турів на підприємстві для збільшення кількості потенційних клієнтів і налагодження співпраці з інвесторами й партнерами.

Аналіз попередніх досліджень: Питання використання і ролі інформаційно-комунікаційних технологій в освіті аналізують В. Биков, Я. Булахова, О. Бондаренко, В. Заболотний, Н. Казакова, Г. Козлакова, О. Міщенко, О. Овчарук, О. Пінчук, Є. Смирнова-Трибульська, О. Спірін, О. Шестопал та ін. Дослідження різних аспектів освітнього та наукового потенціалу мережі Інтернет здійснено в роботах Л. Бородкіна, В. Владімірова, С. Корнієнко та ін. Питанням використання екскурсій як однієї з форм навчальної роботи присвятили свої дослідження Є. Голант, В. Голубков П. Підкасистий, І. Підласий та багато інших. Підстави методології у галузі теорії та практики організації екскурсійної діяльності закладено у наукових доробках В. Бабарицької, Б. Ємельянова, Г. Лєскової, В. Квартальнова, А. Ковальчука та інших. Проблемами впровадження та визначення основних завдань, цілей і перспектив віртуальних технологій в готельно-ресторанному та туристичному бізнесі займаються 3. Гадяцька, Ю. Миронов, В. Шамликашвілі, О. Спориш, М. Багров, О. Шаблій, Л. Мельник, С. Ілляшенко, А. Бейдик, С. Ципящук. Проблематику розвитку віртуального туризму досліджували такі українські вчені $Є$. Борисов, В. Буй, В. Кравченко, Н. Самохвал, О. Сущенко [14] та ін. Сучасні інформаційні системи в системі управління підприємством розглядали О. Єсіна, О. Орлик [8-10] та ін.

\section{II Матеріал і методи дослідження}

Варто зазначити, що на сьогодні віртуальний тур - це актуальний рекламний продукт, який дає змогу показати клієнту товар чи послугу більш наочно, ніж це можна зробити під час перегляду фотографрій і відеороликів, читання описів.

Людина, яка запустила 3D-тур, має можливість потрапити в незнайоме для неї місце. При цьому створюється набагато сильніший ефект присутності, ніж під час перегляду фотографій або відео. Відмінною рисою такого програмного продукту $є$ яскраві образи і сильні враження від побаченого. Оскільки за допомогою 3D-турів легше познайомити людину в невідомими місцями, показавши їх якомога реальніше, віртуальні тури швидко знайшли своє місце в рекламі [5, с. 131].

Специфріка 3D-туру полягає в таких його основних характеристиках, як інтерактивність, показовість, інфрормативність та комунікативність. Віртуальні тури, що дозволяють людині потрапити в цікаве місце в інтерактивному режимі, з кожним днем набувають все більшої популярності. А отже, віртуальний тур - це реальне тривимірне зображення, що складається з циліндричних, сферичних панорам, які зібрані з фотографій, тривимірних об'єктів і активних посилань-переходів (хотспотів). Більшість віртуальних турів дають можливість «рухатися» за допомогою інтерактивних навігаційних клавіш та вказівників їх переходу [2].

Перший віртуальний тур (та й саме визначення) з'явився в 1994 році, у Великобританії. Саме тоді в музеї замку Дадлі (рис.1) створили тривимірну реконструкцію будівлі з можливістю «проходити» приміщеннями, які оформлені в стилі 1550 року.

Цей 3D-тур розробив інженер Колін Джонсон. Його новаторська презентація складалася із системи управління (на комп'ютері) і панорам (на диску). На той час екскурсія замком Дадлі була дуже якісною і продуманою. Оскільки проводилося моделювання будівель, створювалися 3D-моделі для усіх об'єктів, на створення цього віртуального туру було витрачено багато часу. Вигляд 3D-моделей зображено на рис. 2. Спеціально для цієї новаторської презентації була розроблена унікальна програма навігації [4]. 


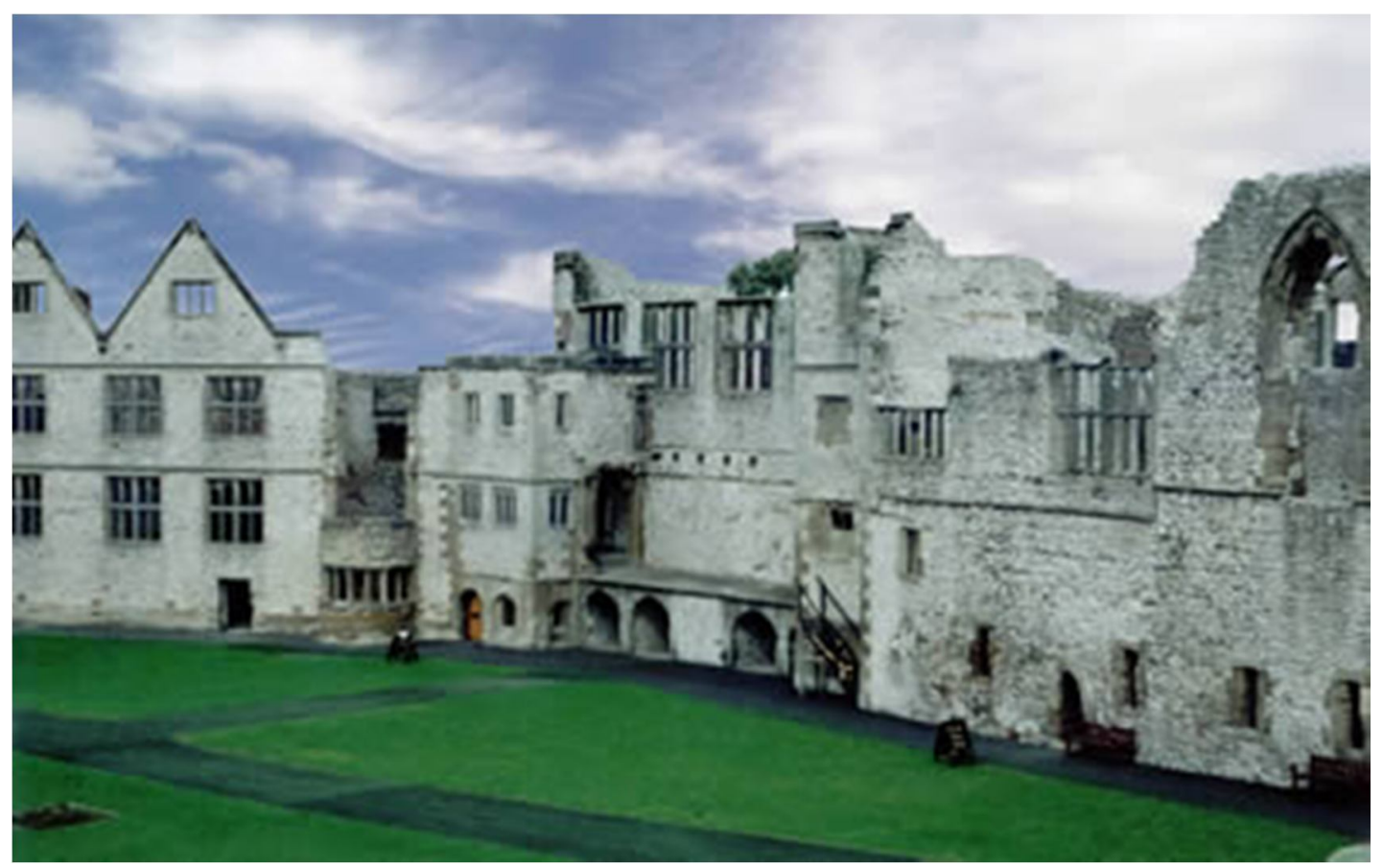

Рис. 1. Замок Дадлі (реальний вигляд)

Пізніше цей віртуальний тур був представлений на конференції Британського музею й описаний в офіційному документі.

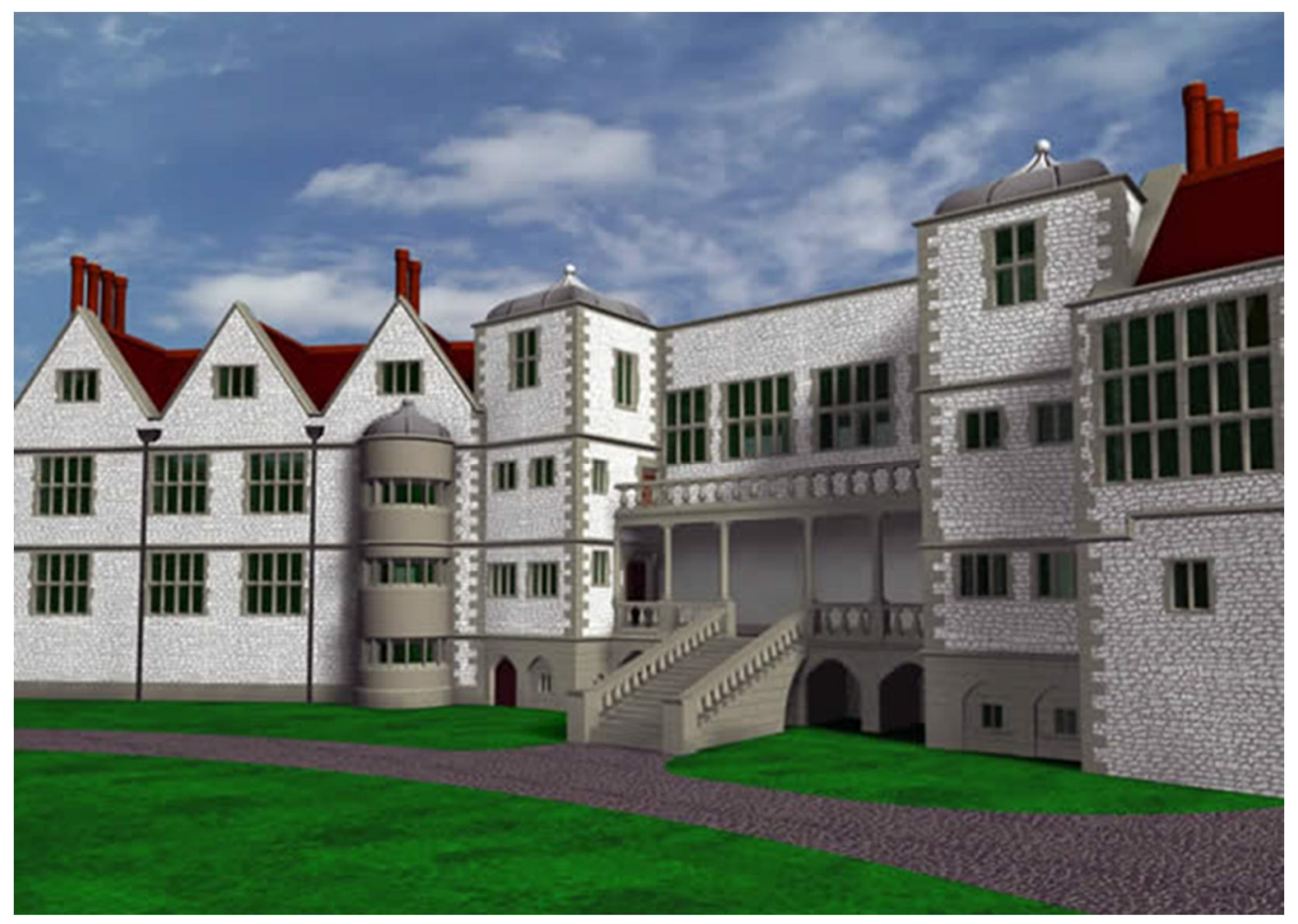

Рис. 2. Замок Дадлі (3D реконструкція)

Як бачимо, історія віртуальних турів почалася з музеїв, які й продовжили цю традицію. Так, сьогодні у всіх великих музеях є 3D-тури: Ватикан, Сикстинська капела; Смітсонівський музей природної історії; Кремль; Колекція Державного Ермітажу; Галерея Уфрфіці; Колекція Фріка; Прадо; Колекція Метрополітен-музею; Російський музей; Реконструкція Третяковки 1898р.; Музей Сальвадора Далі у 
Флориді; Музей східного мистецтва в Чикаго; Скансен в Чернівцях;Лувр;Британський музей; Музей мадам Тюсота інші. Більшість із зазначених вище турів були створені за допомогою GoogleArtProject.

GoogleArtProject - приклад навігації під час віртуальної прогулянки музеєм. Багато чого стало можливим саме завдяки GoogleArtProject, на базі якого створили віртуальні тури в численних музейних залах.

Наступні тури створювалися на базі перших програмних напрацювань. Панорами здебільшого створювалися зі звичайних фоото. Скориставшись безкоштовним онлайн-сервісом для створення віртуальних турів, а також зробивши кілька фото на телефон, сьогодні кожен може самостійно розробити просту інтерактивну прогулянку.

Спочатку інтерактивні прогулянки були некомерційним продуктом, однак сучасні інтерфейси, у тому числі рекламні, створюють все більшу можливість для просування цієї технології не лише в сфері розваг, а й на ринку послуг. Тому створювати новий медіа продукт почати й готелі, розважальні заклади, університети, стадіони, курорти.

Відомо, що на початку 2000-х років кількість 3D-турів стрімко зросла. Поступово продукт вийшов за межі будівель. Особливо стали популярними екскурсійні тури різними пам'ятками природи й зонами відчуження [4].

На жаль, на нашій планеті трапляються техногенні катастрофи і стихійні лиха, які призводять до виникнення зон відчуження, чимало таких місць стають закритими для відвідування. Проте побачити наслідки різних катастроф потрібно обов'язково, оскільки, побачивши масштаби руїн на власні очі, люди стануть діяти більш обдумано.

На нашу думку, такий напрям застосування віртуальних турів неодмінно отримає розвиток і, згодом навчить людей не повторювати помилок у майбутньому.

Найвідомішим віртуальним туром на відчуженій місцевості $є$ екскурсія Чорнобилем. Ентузіасти зняли зону відчуження, і всі бажаючі абсолютно безпечно можуть «ходити їі стежками».

B індустрії нерухомості 3D-тури також надзвичайно популярні. Для дизайнерів і проектувальників - це зручний спосіб представити свої роботи. Віртуальне портфоліо дозволяє масштабно оцінити творчий задум, все розглянути в деталях, відчути обсяг і простір. У ріелторському середовищі віртуальні тури допомагають заощадити час і гроші. Покупець може подивитися квартиру в будь-якій країні, не виходячи з власного будинку, оцінити його інтер'єр і екстер'єр, ознайомитися з особливостями розташування. Багато західних та вітчизняних компаній взяли цю технологію на озброєння і уже спостерігають значне зростання продажів.

Про зручність використання 3D-турів говорить і статистика. За даними Realtor.com на інтернетмайданчики агентств, де можна «поблукати» домівками, заходить на 40\% більше відвідувачів. А $80 \%$ потенційних покупців перед відвідуванням офісу компанії з продажу нерухомості переглядають віртуальні презентації [1].

Для комерційних закладів презентації з подорожами - це питання престижу, для покупців додаткова зручність, оскільки їм пропонується пройтися рядами, розглянути товар, дізнатися, які бренди представлені в різних відділах, і переконатися, що в цьому місці можна знайти необхідну продукцію.

Так само, вибираючи туристичну поїздку, хочеться мати максимально повну інформацію про місце відпочинку, і 3D-тури дозволяють це зробити швидко та ефективно. За допомогою 3D-турів можна побачити екзотичні острови, пам'ятки і культурні центри, розглянути кожен куточок простору, оцінити красу ландшафрту й пейзажі.

Навіть деякі авіакомпанії вже пропонують своїм пасажирам оцінити зручність салонів літаків за допомогою їх віддаленого огляду. 3D-панорами салонів авіалайнерів, купе поїздів, а також внутрішніх приміщень підводних човнів і космічних кораблів - це зручно, пізнавально і захоплююче. Перегляд цих місць допоможе вибрати найбільш відповідний засіб пересування, визначитися з вибором професії і навіть здійснити свою мрію. Так, уже є можливість побувати на знаменитому лайнері «Титанік», побродити палубами, коридорами і залами, оцінити красу інтер'єрів приміщень для знаті і простоту кают для пасажирів третього класу.

Варто зазначити, що сьогодні кожен новий онлайн-тур, який створений серйозною кампанією - це справжня 3D-гра, що має багато опцій (часто $€$ карта або план будівлі 3 покажчиком місця 
розташування; деякі об'єкти не просто сфотографовані, а змодельовані; розширено можливості навігації та інтерактивних посилань).

Зараз технологія настільки доступна, що 3D-тури основних туристичних локацій є практично у всіх містах. Кожна пам'ятка історії, інформація про яку розміщена на сайті, має віртуальну прогулянку. Такий 3D-тур підсилює враження і дає більш чітке уявлення про те чи інше місце. Істотною відмінністю сучасних турів $є$ підвищення якості фотографій. Тому, аби відповідати вимогам сучасних користувачів, навіть вдалі тури десятилітньої давності оновлюються.

Елементами віртуального туру як правило виступають сферичні панорами, які з'єднані між собою інтерактивними посиланнями-переходами. Віртуальний тур, який створений за допомогою сферичних 3D-панорам, є найпопулярнішим у наш час. Віртуальний 3D-тур - один із способів віртуальної трансляції тривимірного простору на екран, що дозволяє отримати максимально точне уявлення про видиму частину продукту або про послугу. Сферична 3D-панорама - це один із видів панорамної фотографії, яка призначена для показу на комп'ютері. В основі сферичної панорами лежить зібране 3 безлічі окремих кадрів зображення у сферичній (рис. 3) або кубічній проекції [13, с. 340].
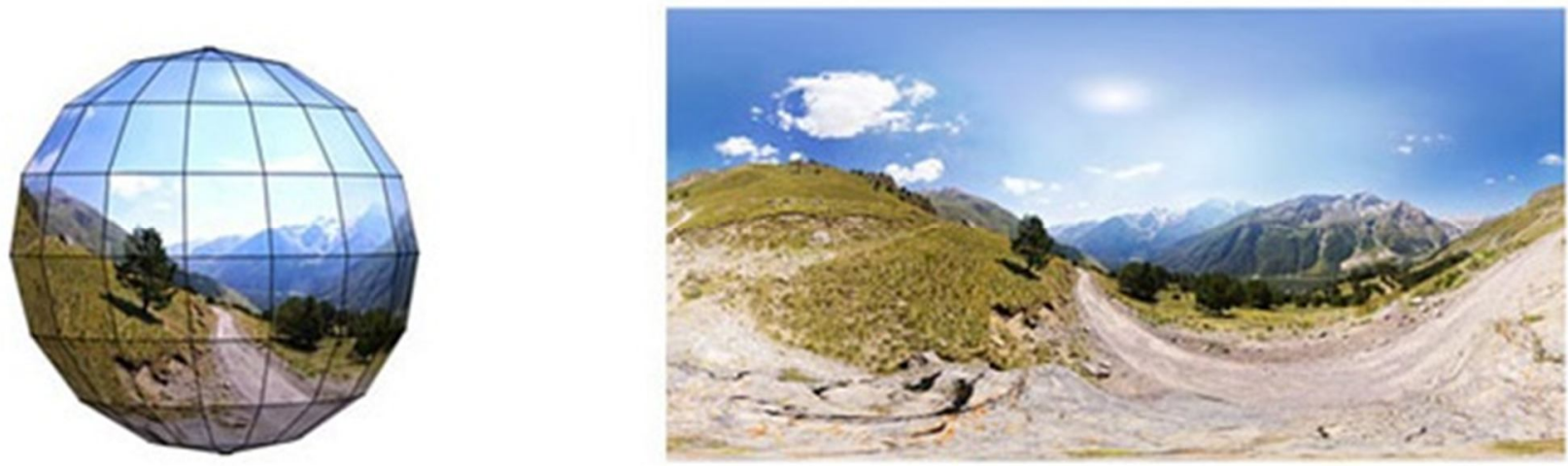

Рис. 3. Сферична панорама

Для покупців перевагою сферичних панорам і 3D-турів, на відміну від інших способів реклами, $\epsilon$ значна економія часу (ознайомитися з об'єктом можна в будь-який зручний для них момент); можливість попереднього, причому досить детального огляду всіх наявних у продавця потенційно цікавих об'єктів.

Для продавців основними перевагами сферичних панорам і 3D-турів, на відміну від інших способів реклами, $є$ підвищення інтересу до компанії, а отже, залучення нових клієнтів (віртуальні тури викликають значний інтерес у більшості відвідувачів, збільшують число можливих клієнтів та підвищують доходи компанії); оригінальність і привабливість (презентація і реклама відмінним від більшості конкурентів способом, що викликає більший інтерес, ніж звичайні фротографрії або текст); скорочення часу між створенням віртуального туру і знайомством з ним покупцем.

Якщо на створення буклету та розповсюдження його серед потенційних клієнтів затрачається багато часу, то віртуальний тур стає доступним мільйонам користувачів Інтернет-мережі практично відразу після його створення; цілодобова доступність (панорами, розміщені на сайтах, доступні для перегляду в будь-який час доби); можливість різноманітного використання таких самих турів як в Інтернеті, так і у вигляді CD-презентацій (їх можна демонструвати в офрісі клієнта, на виставці і т.п.); простота і оперативність розміщення нових, оновлення та заміна старих віртуальних турів.

Віртуальні панорами сприяють підвищенню іміджу компанії її високотехнологічній, інноваційноінвестиційній привабливості (є що показати партнерам).Вони також дають можливість проводити віртуальні екскурсії для нових потенційних клієнтів; демонструвати обладнання салонів, центрів, комплексів і т.д. [6].

Шляхивпровадження віртуальної реальності в Україні, а саме використання цих технологій у бізнесі, на виробництві та в освітінам забезпечила компанія Google. 3 моменту винайдення цієї технології, саме спеціалісти Google почали активно їі досліджувати, вдосконалювати, шукати нові сфери застосування. Так з'явився Google Maps i GoogleBusinessView. 
Україна, незважаючи на всі зусилля прогресивного середовиша і своє унікальне географічне розташування, часто залишається на технологічних «задвірках» цивілізованого світу. Так вийшло і 3 програмою GoogleBusinessView, яка в США і Європі розвивається з 2011 року. На цей час в Україні вже існували компанії з розробки 3D-турів. I коли на ринок прийшла технологія GoogleBusinessView, вона почала активно розширювати свої позиції на ринку.Однак, вважаємо, що така ситуація є тимчасовою, оскількиза рівнем свого маркетингового потенціалу Google панорами інтер'єрів $є$ більш якісними, ніж будь-які альтернативні способи візуалізації простору.

GoogleBusinessView - інструмент створення і виведення в результати пошуку віртуальних 3Dтурів приміщеннями - став доступний для українського бізнесу. У GoogleMaps $€$ функція - StreetView (перегляд вулиць), якою користуються більшість, а також сервіс MyBusiness, що дозволяє створювати картки локальних компаній з прив'язкою до географічних координат і певною адресою на картах. Компанія після реєстрації в Google може розміщувати всю інфрормацію про себе на спеціальній «візитці», яка виводиться в пошуку Google і прив'язана до онлайн-карт. На картці $є$ інформація про діяльність підприємства, план, фотографії, години роботи, передбачена можливість додавати відгуки, прокладати маршрути. Важливим $є$ те, що тепер сюди можна додавати 3D-тури, які створені за технологією Street View.

Отже, GoogleBusinessView - це поєднання технології StreetView iMyBusiness у 3D-тур, який інтегрований в продукти Google. Це і $€$ головною маркетинговою перевагою технології - фактор, який зводить віртуальний тур в ранг повноцінного інструменту продажів.

Щоб зрозуміти, як працює GoogleBusinessView, проаналізуємо, з якою метою створюються звичайні 3D-тури і як вони можуть впливати на продажі. Панорами розташовуються на сервері і можуть бути доступні користувачам сайту. Щоб подивитися 3D-тур, потрібно спочатку знайти сайт, на якому він розміщений. А це означає, що власнику ресурсу як мінімум доведеться витратитися на SEO або контекстну рекламу. Яка користь від 3D-турів Google для бізнесу? 3 Google панорамами інтер'єрів все по-інщому, адже віртуальний тур вже інтегрований в Google за допомогою картки MyBusiness. Це і $€$ основною перевагою продукту, за рахунок якої він з простих гарних картинок перетворюється в маркетинговий механізм.

Що дає комбінація 3D-тур + Google? Ї̈̈ результатом є поява на першій сторінці результатів пошукової видачі за релевантними запитами; надання можливості без вкладення коштів наконтекстну рекламу(SEO) або довге очікування на появу сайту в ТОП-10 у результаті просування. За статистикою Google, наявність віртуального туру компанії підвищує ймовірність бронювання серед молодих людей на 130\%. Тобто, фірмита підприємства, які мають віртуальні тури, що інтегровані в MyBusiness 3 прив'язкою до карт, вибирають в два рази частіше.

За даними MOZ (веб-ресурс, який займається підняттям рейтингу сайтів в пошукових системах), наявність в Google 3D-туру є позитивним фактором ранжирування сайту, прив'язаного до картки MyBusiness. Якщо на певному виробництві є віртуальний тур в Google, то за інших рівних умов, позиції сайту за результатами органічної видачі будуть вищими, ніж у конкурентів [18].

\section{III Результати}

Панорами інтер'єрів Google є універсальними. Такі 3D-тури легко вбудовуються в звичайні сайти, інтегруються в каталоги, сторінки соціальних мереж, потрібно лише скопіювати і встановити код. Український бізнес отримав можливість пропонувати віртуальні екскурсії об'єктами ще на етапі пошуку інформації в інтернеті, а також отримати цільовий трафік з найпопулярнішої пошукової системи. Така технологія активно розвивається в Україні і незабаром стане повсякденним інструментом просування бізнесу в мережі [11].

Для прикладу робіт командиGoogleiз впровадження віртуальних турів можемо взяти завод «Запоріжсталь». У 2017 році у Запоріжжі працювали спеціалісти компанії Google, які займались зйомкою цього заводу у форматі 360 градусів. На основі результатів цих зйомок було створено віртуальний панорамний 3D-тур у режимі StreetView комбінатом. Для цього спеціалісти компанії відзняли зсередини основні локації комбінату: цехи та нові об'єкти підприємства. Головною перевагою онлайн-екскурсії стало поліпшення інвестиційної привабливості комбінату, можливість оцінити масштаби виробничого процесу людьми, які лише знайомляться з діяльністю компанії [18]. 
Віртуальний тур Корпорацією «Артеріум» доповнений екскурсією на виробництво інфузійних препаратів. Це нова, найбільша за площею, виробнича лінія «Галичфарм». Віртуальний тур дозволяє дізнатися, з яких етапів складається виробництво інфузійних препаратів, чим воно відрізняється від інших виробничих дільниць; побачити, як виглядає та працює велике і складне обладнання; подивитися, як відбувається розлив інфузійних препаратів у фрлакони і навіть зазирнути всередину обладнання, що під час звичайної екскурсії зробити неможливо.

У 2014 році Корпорація «Артеріум» першою серед українських фармацевтичних компаній запропонувала усім бажаючим відвідати віртуальну екскурсію на свої підприємства. Потрапити на екскурсію на виробництво не просто, адже більшість виробничих дільниць $є$ стерильними зонами, що виключає присутність людини. 3D-тур «Артеріум» (рис. 4) дає можливість в будь-який час кожному бажаючому відвідати з віртуальною екскурсією підприємства, які виготовляють продукцію під брендом «Артеріум» [7].

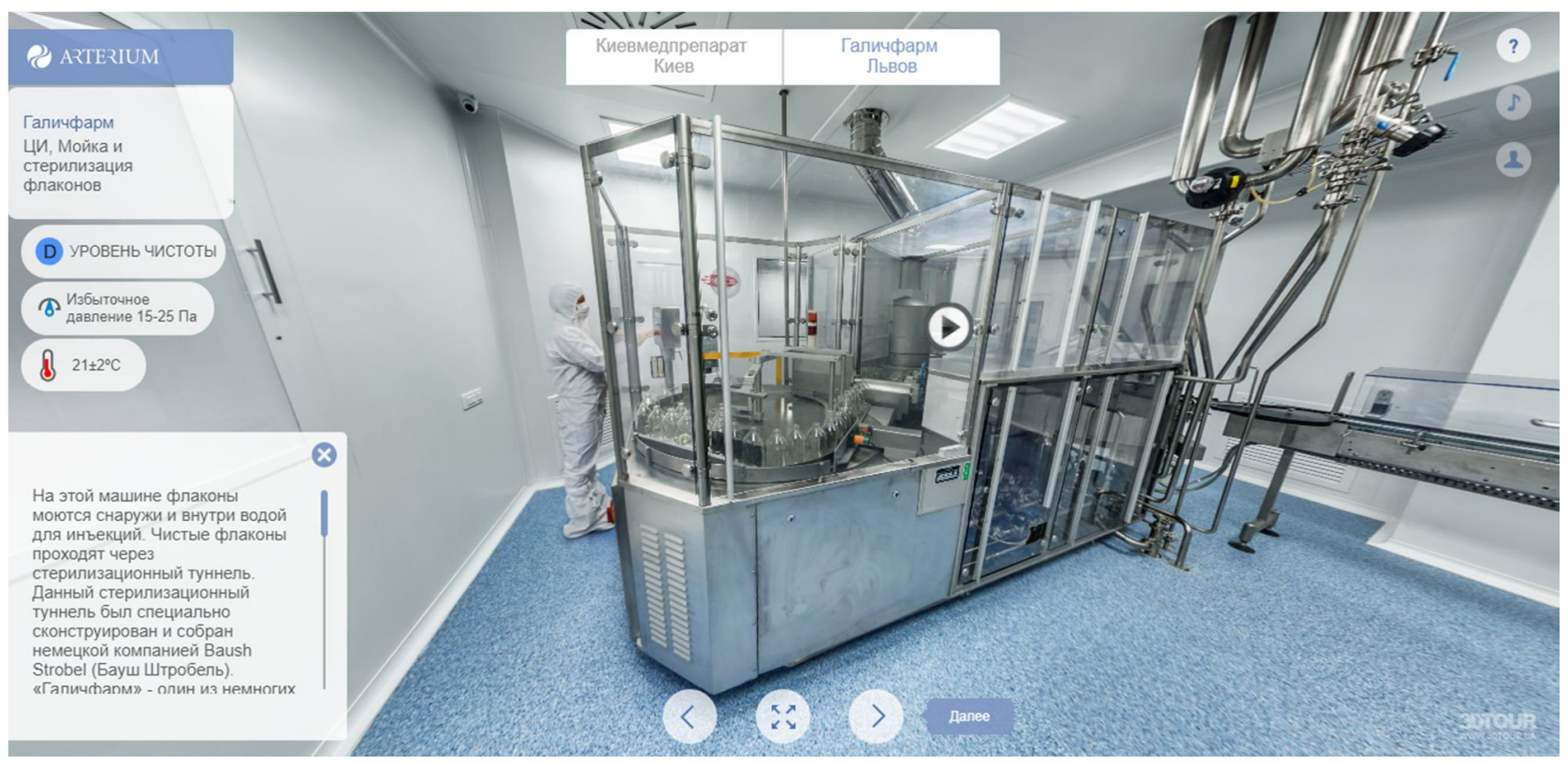

Рис. 4. Віртуальний тур «Артеріум»

Варто зазначити, що технічна сторона розробки віртуального туру Корпорацією «Артеріум» $є$ досить складною. Переглядаючи тур, ми виділили такі його особливості:

- на панорамах є чимало додаткової інформації про приміщення, в якому знаходиться глядач;

- відеофрагменти процесу роботи конвеєра;

- усі панорами туру озвучені диктором;

Усі згадані вище додаткові елементи інтерфейсу за необхідності можна вмикати і вимикати.

Компанія з розробки віртуальних турів Viemr розробила тур фабрикою,яка розташована в Ансені

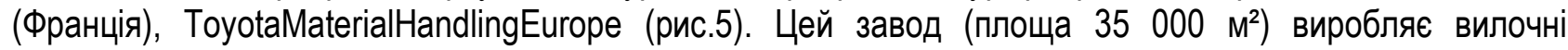
навантажувачі для європейського ринку (бензинові двигуни і електронавантажувачі від 1,5 до 5 тонн). Маркетологи Toyota зацікавились питанням, як можна пояснити постачальникам і клієнтам, які знаходяться на далекій відстані, принцип роботи їх складальної лінії. Також необхідно було створити умови для кращої взаємодії з клієнтами на виставкових майданчиках. Розробники обрали концепцію сповільненої зйомки віртуальної реальності, в якій глядачі опиняються в центрі усіх подій. Камера, яка розміщена в електронавантажувачі, дає змогу спостерігати за усіма виробничими процесами в реальному часі [21].

Міжнародний досвід впровадження віртуальних турів переконливо доводить, що такий напрям діяльності створює умови для підвищення конкурентоспроможності. Такий продукт, який презентований у вигляді віртуального туру є «інформаційно місткішим», презентабельнішим і привабливішим [14, с. 21]. 


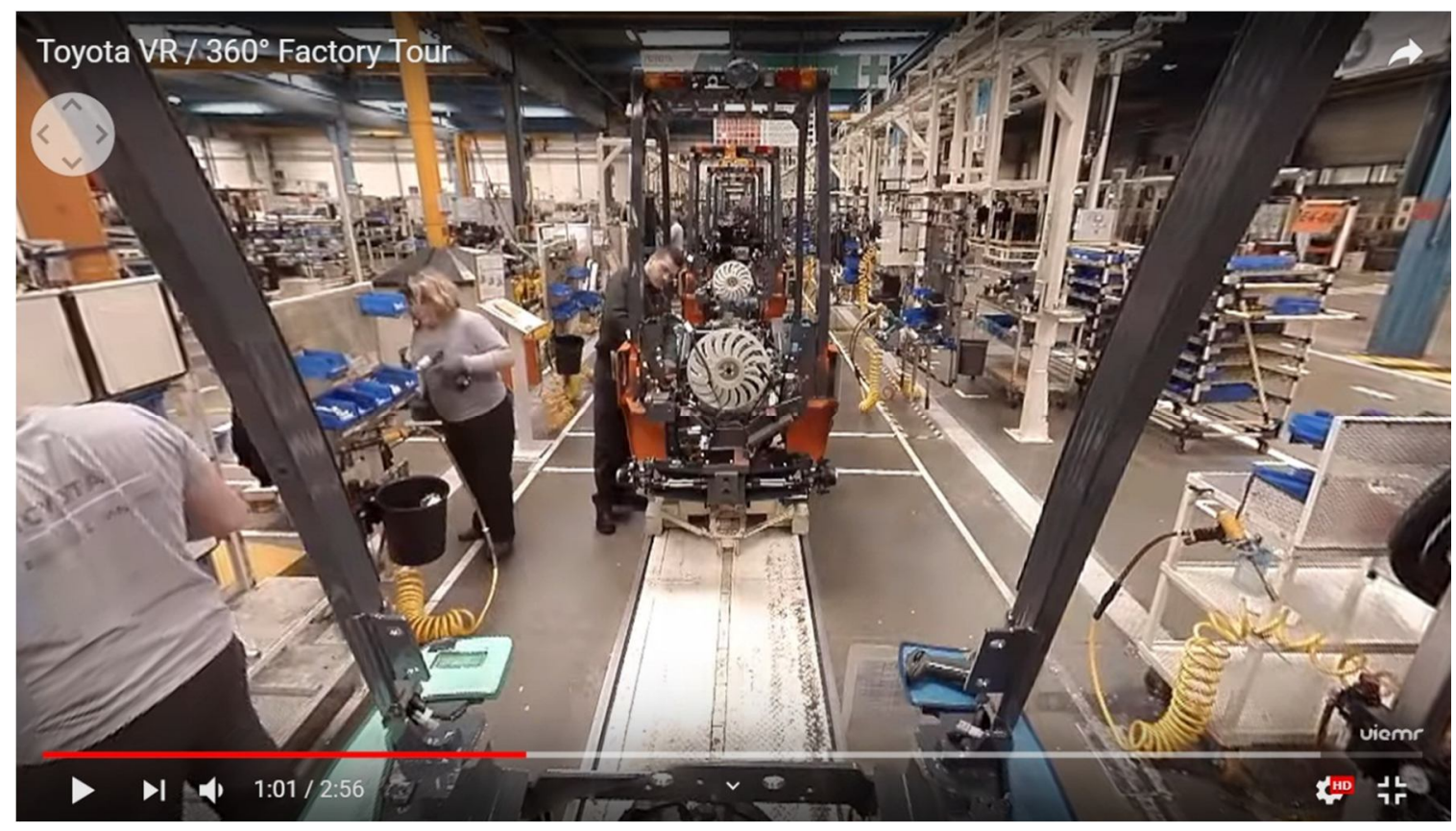

Рис. 5. Віртуальний тур «Тоуоtа»

У рамках проекту «Цифрове перетворення регіонів України» команда Google запустила низку проектів, внаслідок чого було створено туристичний сайт про Івано-Франківську область - «Мандруй Івано-Франківщиною» (рис. 6), де зібрані дані про найкращі місця Прикарпаття.Так, на сайті можна знайти 3D-тури різними пам'ятками і курортами («Буковель», «Манявський Скит», обсерваторія на горі Піп Іван, «Скелі Довбуша»). Разом з тим тут зібрана інформацію про те, де можна зупинитися; усі контакти, а також фрото і відео місць, якими цікавляться туристи. На сайті $є$ також окремий сервіс «Сплануй поїздку», за допомогою якого можна скласти маршрут, враховуючи ті пам'ятки, які хотілося б подивитися, а також місця для проживання, харчування і т. д. Компанія Google створила цей сайт у співпраці з Івано-Франківською облдержадміністрацією та міською радою обласного центру [12].

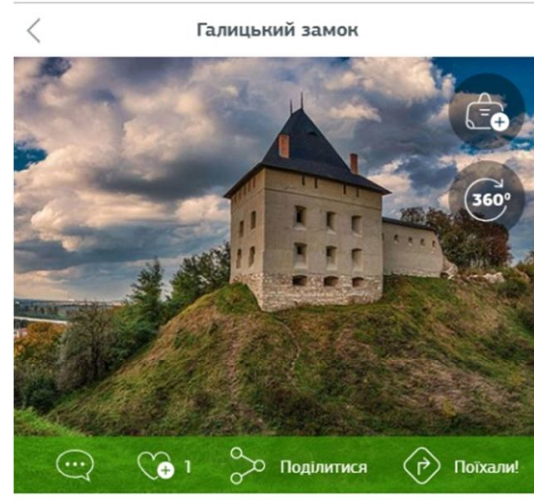

Галицький замок

Галицький замок або Старостинський замок спочатку був дерев'яним і вперше згадується 1114 р. як укріплена цитадель.

Детальніше

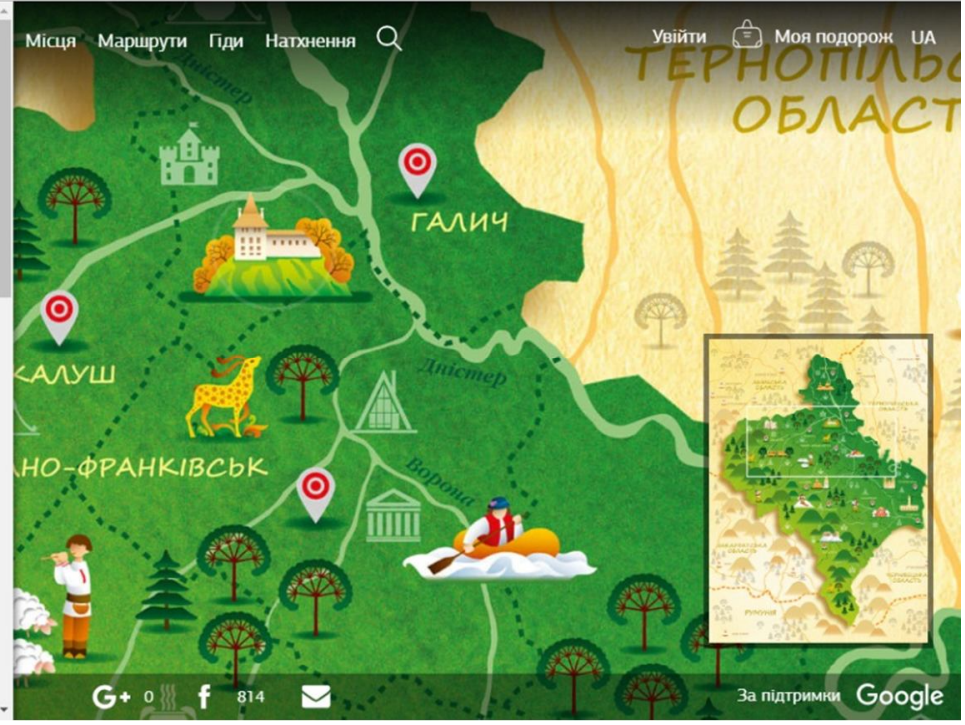

Рис. 6. Віртуальний тур «Мандруй Івано-Франківщиною»

\section{IV Обговорення}

Як бачимо, розширення сучасного бізнесу пов'язане зі збільшенням числа постійних клієнтів, а також співпрацею з інвесторами і партнерами. Під час опрацювання теми дослідження виділили наступні переваги і недоліки віртуальних турів, які зазначені у табл.1. 
Табл. 1. Переваги і недоліки віртуальних турів

\begin{tabular}{|l|l|}
\hline \multicolumn{1}{|c|}{ Переваги } & \multicolumn{1}{|c|}{ Недоліки } \\
\hline $\begin{array}{l}\text { Доступність (можливість огляду будь-яких об'єктів } \\
\text { без матеріальних витрат) }\end{array}$ & $\begin{array}{l}\text { Неможливо поставити питання в ході перегляду } \\
\text { туру }\end{array}$ \\
\hline $\begin{array}{l}\text { Багаторазовість (можливість багаторазового } \\
\text { перегляду 3D-туру) }\end{array}$ & $\begin{array}{l}\text { Залежність від розробників (професіоналізм } \\
\text { розробників є визначальним фактором кінцевої } \\
\text { якості продукту) }\end{array}$ \\
\hline $\begin{array}{l}\text { Постійність (тур можна переглянути будь-де і } \\
\text { будь-коли) }\end{array}$ & - \\
\hline $\begin{array}{l}\text { Вартість (доступна вартість впровадження } \\
\text { технології) }\end{array}$ & - \\
\hline Простота у використанні & - \\
\hline Збільшення зацікавленістю компанією & - \\
\hline
\end{tabular}

Разом з тим необхідно звернути увагу на зазначені нижче загрози, які виникають під час впровадження віртуального туру:

- поява нових конкурентів, що впровадять аналогічну технологію;

- зміна вигляду виробничих приміщень;

- застарілість методів розробки;

- не окупність нововведення.

Отже, розглянувши всі переваги і недоліки створення віртуальних турів, загроз підчас їх впровадження, вважаємо доцільним розробити алгоритм дій компанії, яка бажає створити такий тур. Послідовність дій компанії щодо впровадження віртуального туру умовно можна розділити на 4 етапи:

Етап 1. Вибір розробника.

Визначитися з розробником не так просто, тому необхідним $є$ чітке формулювання цілей і завдань проекту. На ринку таких послуг представлена велика кількість фірм, які подібні за своєю специфікою роботи. Для кращого вибору варто сформувати попередній список з 10-15 фірм. Основними критеріями відбору повинні служити: портфолліо (не менше 5 якісних турів), досвід професійної діяльності (від 3-х років присутності на ринку), відгуки в Мережі, до яких слід ставитися з певною часткою скепсису. Доцільно також включити в критерії вибору додаткові позиції: додаткову відео-зйомку; деталізацію вартості послуг і ресурсів, задіяних в розробці; умови гарантійного обслуговування.

Етап 2. Складання технічного завдання.

Реалізації будь-якого проекту передує планування - постановка цілей і завдань, а також визначення шляхів їх вирішення. Щоб передати всі або частину функцій стороннім фахівцям, необхідно розробити й узгодити технічне завдання (Т3), яке буде служити керівництвом до подальших дій. Технічне завдання зазвичай включає такі положення:

- словник термінів і визначень, які використовуються нижче по тексту технічного завдання. Він необхідний для того, щоб замовник і виконавець однаково інтерпретували використовувані поняття;

- комплекс вимог до реалізації проекту щодо: ергономіки та естетики (оптимізації під екрани різних пристроїв без смуг прокручувань і порожніх полів); умов здачі-приймання завершеного проекту, включаючи: дотримання термінів поетапного графіка робіт; формати і обсяг передачі матеріалів інформаційного наповнення виконавцю; порядок надання дистрибутива і перенесення туру на сайт; період безкоштовного виправлення допущених розробниками помилок після прийняття проекту;

- права і обов'язки обох сторін, в тому числі можливість і допустимі межі змін / доповнень Т3 в процесі роботи над розробкою, які спрямовані на усунення спірних моментів і поліпшення якості майбутнього продукту. Чим глибше технічне завдання описує усі аспекти створення туру, тим менше виникатиме розбіжностей і точніше буде визначена кінцева вартість проекту.

Етап 3. Розробка віртуального туру.

Вимоги до розроблюваного туру починаються з формулювання побажань. Наприклад: структури віртуального туру, розміщення додаткової інформації, накладання фонового звуку для більшої 
інформативності. Загалом процес розробки туру майже повністю закладається в технічне завдання, і від якості його складання залежить результат.

Етап 4. Подальша технічна підтримка.

Технічна підтримка необхідна для корекції помилок у структурі туру, або у його відображенні на екрані користувача.

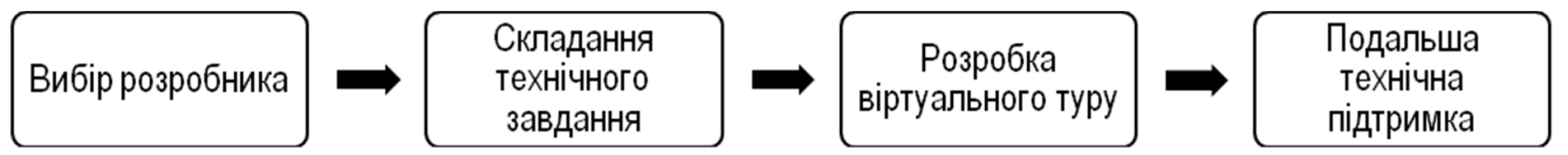

Рис. 7. Алгоритм дій компанії замовника віртуального туру

Отже, віртуальний тур виробництвом може стати ефективним маркетинговим інструментом, який демонструє потенційним і реальним замовникам особливості виготовлення продукції і здійснення технологічних процесів; дозволяє підкреслити основні переваги виробництва (наприклад, технічну оснащеність, займану площу і т.д.).

\section{V Висновки}

Узагальнюючи сказане вище, приходимо до висновку, що віртуальний тур визначається як горизонтальна 360-градусна панорамна презентація, яку можна переглядати як з традиційного настільного комп'ютера, так і з мобільного пристрою. Ця відносно нова технологія створення віртуальних турів пройшла довгий шлях: від експериментального нововведення до потужного інструменту візуалізації середовища. Віртуальні тури можна застосовувати в будь-якій сфері діяльності. Ця технологія може відтворити реальність найкращим чином. Аби створення віртуальних турів на виробництві пройшло успішно, необхідно дотримуватись алгоритму зазначеного вище алгоритму дій та рекомендацій. У результаті отримаємо можливість збільшити кількість постійних клієнтів і налагодити співпрацю з інвесторами й партнерами.

\section{Бібліографрічні посилання}

[1] Актуальность виртуальных туров в современном мире, их польза и перспективы URL: http://blog.flexyheat.ru/aktualnost-virtualnyx-turov-v-sovremennom-mire-ix-polza-i-perspektivy (дата звернення 10.12.2018).

[2] Ветрова А. А., Макаренко А. Ю. Создание конструктора для разработки виртуальных 2D и 3D экскурсий / Прикаспийский журнал: управление и высокие технологии. 2008. № (2). URL: http://hi-tech.asu.edu.ru/files/2(2)/9195.pdf (дата звернення 10.12.2018).

[3] История возникновения и развитие виртуальных туров. URL: http://blog.flexyheat.ru/istoriya-vozniknoveniya-i-razvitievirtualnyx-turov (дата звернення 10.12.2018).

[4] Буй В. М. Інформаційні системи в економіці / Матеріали Всеукраїнської наукової конференції аспірантів та молодих вчених «Гармонізація суспільства - новітній напрямок розвитку держави». Одеса: ОНЕУ, 2014. С. 109-116.

[5] Масовець О. А. Історія створення віртуальних турів / Матеріали III Всеукраїнської науково-практичної інтернетконференції «Управління ресурсним забезпеченням господарської діяльності підприємств реального сектору економіки». Полтава: РВВ ПДАА, 2018. С. 131-133.

[6] Навіщо використовувати віртуальні тури. Віртуальні Карпати. URL: https://xn--3-7sbar0a5ags5f.com/uk/primenenie.html. (дата звернення 10.12.2018).

[7] Оновлений 3D-тур фрармацевтичним виробництвом URL: http://www.arterium.ua/post/onovlenii_3d_tur_po_ farmatsevtichnomu_virobnitstvu (дата звернення 10.12.2018).

[8] Орлик О. В. Інформаційні системи в сфрері управління організацією / Вісник соціальноекономічних досліджень. Одеса. 2002. Вип. 12. С. 188-191.

[9] Орлик О. В. Інформаційні системи як стратегічній засіб розвитку фірми / Вісник соціально-економічних досліджень. Одеса. 2001. Вип. 10. С. 386-390.

[10] Орлик О. В. Сучасні інформаційні технології в системі управління підприємством / Вісник соціально-економічних досліджень. Одеса. 2002. Вип. 11. С. 293-296.

[11] Перехрест O. Google створив віртуальний тур по «Запоріжсталі». URL: https: //zaxid.net/google_stvoriv_virtualniy_tur_ po_zaporizhstali_n1433225 (дата звернення 10.12.2018).

[12] Пиріг В. Google запустив туристичний сайт про Івано-Франківську область. URL: https://zaxid.net/ google_ zapustiv_turistichniy_sayt_pro_ivanofrankivsku_oblast_n1411035 (дата звернення 10.12.2018). 
[13] Потапюк Л. М., Масовець О. А. Застосування технологій віртуальної реальності в освіті / Сучасна наука та освіта Волині : зб. матеріалів науково-практ. конфф., 22 листоп. 2018 р., м. Володимир-Волинський ; упоряд. голов. ред. Б. Є. Жулковський. Луцьк: Волинь поліграф, 2018. С. 338-343.

[14] Сущенко О. А., Кравченко В.В. Становлення віртуального туризму як напряму розвитку інфрорматизації діяльності туристичного підприємства / Комунальне господарство міст. Харків. 2018. Вип. 140. С. 19-24.

[15] Bailly, F., McClendon, B. (2011). Virtual tour of user-defined paths in a geographic information system. US Patent 7,933,395, 2011.

[16] Bouta, H., Retalis, S., Paraskeva, F. (2012). Utilising a collaborative macro-script to enhance student engagement: A mixed method study in a 3D virtual environment. Computers \& Education, 58 (1), 501-517.

[17] Cunha, M. M., Putnik G. D. (2006). BM_Virtual Enterprise as an Agile/Virtual Enterprise Model. Agile Virtual Enterprises, 8097. https://doi.org/10.4018/978-1-59904-010-3.ch003 (дата звернення 07.01.2019).

[18] Google Business View: «новый» инструмент наконец-то стал доступен для украинского бизнеса URL: https://blog.uamaster.com/google-business-view (дата звернення 10.12.2018).

[19] Sussmann, S. \& Vanhegan, H. (2000). Virtual reality and the tourism product: substitution or complement? Retrieved from: http://www.indjst.org/index.php/indjst/article/view/3051

[20] Sushchenko, O. A. (2016). Design of a tourism enterprise based on its competitive advantages. Vybrané ekonomické problémy region střední a východní Evropy. České Budějovice: Vysoká škola evropských a regionálních studií. 59-71.

[21] Toyota VR. $360^{\circ}$ FactoryTour. URL: https://viemr.com/portfolio/toyota (дата звернення 10.12.2018).

[22] Williams, A.P. (1995). Virtual reality and tourism: fact or fantasy? Tourism Management, 16 (6), 423-427.

\section{References}

[1] Aktualnost vyrtualnykh turov v sovremennom myre, ykh polza y perspektyvy (2016). URL: http://blog.flexyheat.ru/aktualnostvirtualnyx-turov-v-sovremennom-mire-ix-polza-i-perspektivy/ [in Russian].

[2] Vetrova A. A. (2008). Sozdanye konstruktora dlia razrabotky vyrtualnykh 2D y 3D эkskursyi. Prykaspyiskyi zhurnal: upravlenye y vysokye tekhnolohyy № (2). URL: http://hi-tech.asu.edu.ru/files/2(2)/91-95.pdf/ [in Russian].

[3] Ystoryia voznyknovenyia y razvytye vyrtualnykh turov (2016). URL: http://blog.flexyheat.ru/istoriya-vozniknoveniya-i-razvitievirtualnyx-turov/ [in Russian].

[4] Bui V. M. (2014). Informatsiini systemy v ekonomitsi. Materialy Vseukrainskoi naukovoi konferentsii aspirantiv ta molodykh vchenykh «Harmonizatsiia suspilstva - novitnii napriamok rozvytku derzhavy». Odesa: ONEU, S. 109-116. [in Ukrainian].

[5] Masovets O. A. (2018). Istoriia stvorennia virtualnykh turiv / Materialy III Vseukrainskoi naukovo-praktychnoi internetkonferentsii «Upravlinnia resursnym zabezpechenniam hospodarskoi diialnosti pidpryiemstv realnoho sektoru ekonomiky». Poltava: RVV PDAA, S. 131-133. [in Ukrainian].

[6] Navishcho vykorystovuvaty virtualni tury (2018). URL: https://xn--3-7sbar0a5ags5f.com/uk/primenenie.html. [in Ukrainian].

[7] Onovlenyi 3D-tur farmatsevtychnym vyrobnytstvom (2016). URL: http://www.arterium.ua/post/onovlenii_3d_tur_po_farmatsevtichnomu_virobnitstvu [in Ukrainian].

[8] Orlyk O. V. (2002). Informatsiini systemy v sferi upravlinnia orhanizatsiieiu / Visnyk sotsialnoekonomichnykh doslidzhen. Odesa. Vyp. 12. S. 188-191. [in Ukrainian].

[9] Orlyk O. V. (2001). Informatsiini systemy yak stratehichnii zasib rozvytku firmy / Visnyk sotsialno-ekonomichnykh doslidzhen. Odesa. Vyp. 10. S. 386-390. [in Ukrainian].

[10] Orlyk O. V. (2002). Suchasni informatsiini tekhnolohii v systemi upravlinnia pidpryiemstvom / Visnyk sotsialnoekonomichnykh doslidzhen. Odesa. Vyp. 11. S. 293-296. [in Ukrainian].

[11] Perekhrest O. (2017). Google stvoryv virtualnyi tur po «Zaporizhstali». URL:. https://zaxid.net/google_stvoriv_virtualniy_tur_po_zaporizhstali_n1433225 [in Ukrainian].

[12] Pyrih V. (2016). Google zapustyv turystychnyi sait pro Ivano-Frankivsku oblast.. URL: https://zaxid.net/google_zapustiv_turistichniy_sayt_pro_ivanofrankivsku_oblast_n1411035 [in Ukrainian].

[13] Potapiuk L. M. (2018). Zastosuvannia tekhnolohii virtualnoi realnosti v osviti.Suchasna nauka ta osvita Volyni : zb. materialiv naukovo-prakt. konf., 22 lystop. 2018 r., m. Volodymyr-Volynskyi / uporiad. holov. red. B. Ye. Zhulkovskyi. Lutsk: Volyn polihraf, S. 537-540. [in Ukrainian].

[14] Sushchenko O. A., Kravchenko V.V. (2018). Stanovlennia virtualnoho turyzmu yak napriamu rozvytku informatyzatsii diialnosti turystychnoho pidpryiemstva / Komunalne hospodarstvo mist. Kharkiv. Vyp. 140. S. 19-24. [in Ukrainian].

[15] Bailly, F., McClendon, B. (2011). Virtual tour of user-defined paths in a geographic information system. US Patent 7,933,395, 2011. [in English].

[16] Bouta, H., Retalis, S., Paraskeva, F. (2012). Utilising a collaborative macro-script to enhance student engagement: A mixed method study in a 3D virtual environment. Computers \& Education, 58 (1), 501-517. [in English].

[17] Cunha, M. M., Putnik G. D. (2006). BM_Virtual Enterprise as an Agile/Virtual Enterprise Model. Agile Virtual Enterprises, 8097. URL: https://doi.org/10.4018/978-1-59904-010-3.ch003 [in English].

[18] Google Business View: «novyi» ynstrument nakonets-to stal dostupen dlia ukraynskoho byznesa (2016). URL:. https://blog.uamaster.com/google-business-view. [in Russian].

[19] Sussmann, S. \& Vanhegan, H. (2000). Virtual reality and the tourism product: substitution or complement? URL:: http://www.indjst.org/index.php/indjst/article/view/3051 [in English]. 
[20] Sushchenko, O. A. (2016). Design of a tourism enterprise based on its competitive advantages. Vybrané ekonomické problémy region střední a východní Evropy. České Budějovice: Vysoká škola evropských a regionálních studií. 59-71. [in English].

[21] Toyota VR / 360 FactoryTour (2016). URL: https://viemr.com/portfolio/toyota [in English].

[22] Williams, A.P. (1995). Virtual reality and tourism: fact or fantasy? Tourism Management, 16 (6), 423-427. [in English].

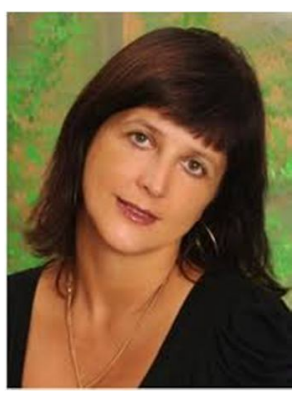

\section{Потапюк Лілія Миколаївна.}

К.пед.н., доцент, доцент кафредри комп'ютерних технологій та профресійної освіти, Луцький національний технічний університет, вул. Львівська, 75, м. Луцьк, Волинської обл., Україна, 43018. Тел. +38(050) 17-27-719. E-mail: potapiuk_|@bigmir.net

\section{Potapiuk Liliia Mykolaivna.}

Ph.D. in Pedagogics, Associate Professor, Associate Professor of the Department of Computer Technologies and Vocational Education. Lutsk National Technical University,

75, Lvivska str., Lutsk, Volyn Region, Ukraine, 43018.

Tel. +38(050) 17-27-719. E-mail: potapiuk_@@bigmir.net

ORCID: 0000000308308758

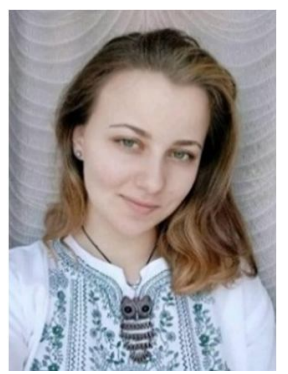

Масовець Олена Андріївна.

Здобувач вищої освіти, Луцький національний технічний університет, вул. Львівська, 75, м. Луцьк, Волинської обл., Україна, 43018.

Тел. +38(099) 52-31-224. E-mail: oleno4ka16@ukr.net

\section{Masovets Olena Andriivna.}

Student of Higher Education, Lutsk National Technical University,

75, Lvivska str., Lutsk, Volyn Region, Ukraine, 43018.

Tel. +38(099) 52-31-224. E-mail: oleno4ka16@ukr.net

\section{Citation (APA):}

Potapiuk, L., Masovets, O. (2019). Virtual tour as an effective method for promotion of enterprise. Engineering and Educational Technologies, 7 (1), 66-78. doi: https://doi.org/10.30929/2307-9770.2019.07.01.07

\section{Цитування (ДСТУ 8302:2015):}

Потапюк Л. М., Масовець О. А. Віртуальний тур як ефективний спосіб просування підприємства / Інженерні та освітні технології. 2019. Т. 7. № 1. С. 66-78. doi: https://doi.org/10.30929/2307-9770.2019.07.01.07

Обсяг статmi: $\quad$ сторінок-13 ; умовних друк. аркушів - 1,494. 